\title{
UK science budget avoids the spending axe
}

London. Britain's scientific community last week gave a collective sigh of relief as the government announced that it had decided to hold constant the $£ 1.3$ billion annual science budget in real terms for 1995-96, despite pressure to reduce public spending to help finance a one per cent cut in the basic rate of income tax.

But there remains concern that much of the extra $£ 30$ million being awarded to the research councils to keep up with inflation will be swallowed up by increased subscriptions to international facilities - in particular the European Laboratory for Particle Physics (CERN) and the European Space Agency - due to the falling value of the pound.

John Mulvey, of the pressure group Save British Science, said that he congratulated Ian Lang, president of the Board of Trade, who has cabinet responsibility for science, for protecting the science budget. "We ought to give him credit for a good job," says Mulvey, one of a number of critics to suggest that last July's transfer of the Office of Science and Technology (OST) to the Board of Trade amounted to a step down for science. Lang has "done well to retain science spending", he concedes.

Richard Brook, chief executive of the Engineering and Physical Sciences Research Council, said that scientists could take "broad comfort" from the fact that funding levels had been held up. "We should credit the OST with having held the government's loyalty to science through what everyone agrees has been a difficult budget," he said last week.

News of the science budget was also welcomed by Sir Michael Atiyah, outgoing president of the Royal Society, which receives a share of the budget along with the research councils, the Royal Academy of Engineering and the special initiatives that are overseen by the OST. At the same time, however, both Mulvey and Atiyah point out that the government's budget statement included projected annual cuts to science spending of around $£ 14$ million over the following three years.

Mulvey, in addition, says he is concerned at the fall in capital funding for universities, part of the education budget, by $£ 300$ million in real terms. "The science base stands on two legs: research councils and the universities higher education funding council," says Mulvey. "We now have a situation where one leg has done well, while the other has been hacked off."

Kenneth Pounds, chief executive of the Particle Physics and Astronomy Research Council (PPARC), says he "shares the relief of other research councils" that the budget has been held steady. But he remains concerned about how much of PPARC's budget will be used to pay Britain's subscription to CERN and ESA. "We can be certain it will go up," he says, although refusing to confirm rumours that additional costs may be as high as $£ 20$ million.

As a result of changes introduced as part of the White Paper of 1993, this extra cost will now be shared by all the research councils, although there is still discussion taking place as to the size of the share that PPARC should shoulder during the current transitional period. A statement on the CERN subscription is expected this week.

Allocations for the science budget between the six research councils will be announced early in 1996. Ehsan Masood

\section{Rabbit virus threatens ecology after leaping the fence}

Sydney. The Australian government is considering whether to bow to the inevitable and officially release a rabbit virus that escaped from its test site on a remote island in late October. But some Australian scientists are predicting a wave of extinctions following the breakout of rabbit calicivirus disease (RCD) virus, two years before it was due to be officially released as a biological control.

Few in Australia have been sorry to see the deaths of at least one million rabbits by the end of November, as rabbits are regarded as vermin. But they had also become natural prey for other animals, such as foxes and feral cats.

State and federal departments of agriculture have started culling those predators. But Glenn Albrecht, a lecturer at the University of Newcastle's geography department, and a vocal critic of the RCD programme, says that the ad hoc and rushed culling programme will not save many species. "There is potential for major ecological damage to Australia," he says, in part "through a mass wave of extinctions due to prey switching".

$\mathrm{RCD}$ is a naturally occurring virus. It killed millions of rabbits in China and Europe during the 1980 s, without seeming to harm other species, and was therefore an obvious candidate for use as a biological control in Australia.

Apart from competing with native animals for food and destroying native vegeta- tion, rabbits cost farmers an estimated A $\$ 120$ million (US\$89 million) a year.

One attempt has been made to eradicate rabbits with the mosquito-borne disease myxomatosis, which was also prematurely released in the $1950 \mathrm{~s}$. But although the disease still works to a certain extent, the rabbit population has built up an immunity to it and is almost back to its premyxomatosis levels.

After extensively testing RCD virus on a range of native animals and finding it had no effect, the RCD committee, which includes scientists from a number of organizations, was testing its effects on rabbit populations on Wardang Island, off the coast of South Australia. A spokesman for the RCD com-

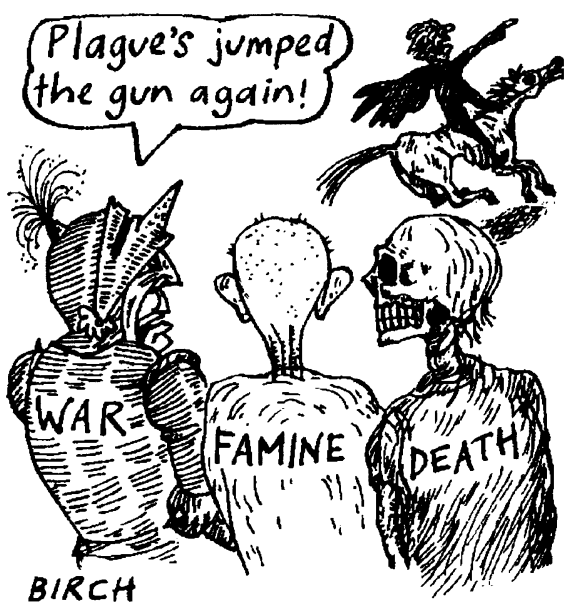

mittee said it is still did not know how the virus escaped from the island. The best guess was that it was spread by bush flies (also very common in Australia), aided by warm weather and a strong southerly wind.

$\mathrm{He}$ said the virus now appeared to be spreading north and west but not towards the east, after initially getting as far as the mining town of Broken Hill, over the state border in New South Wales. He said that the pattern of spread appeared to be related to rabbit population density.

Faced with the reality of the premature release of $\mathrm{RCD}$, the Biological Control Authority, which reports to a joint committee of state and federal government ministers responsible for agriculture and resource management, has called for submissions on whether RCD should be officially released. It will also decide whether to recommend an official inquiry into the reason for the outbreak.

Whatever its cause, the premature release has led Australian scientists and conservationists to question whether scientific procedures for testing viruses are at all adequate, and even the need for biological controls.

Stuart Pearson, who along with Albrecht is also a lecturer at the University of Newcastle's department of geography, says that there is still a small risk of Australian mammals being infected by RCD, as not all have been tested for their reaction to the virus.
Mark Lawson 